\title{
FAKTOR-FAKTOR YANG MEMPENGARUHI KUALITAS LAPORAN KEUANGAN PEMERINTAH DAERAH DI KABUPATEN KEPULAUAN TALAUD
}

\author{
Imelda Latjandu, Lintje Kalangi, Jantje J. Tinangon \\ (Email: imelda.latjandu@gmail.com)
}

\begin{abstract}
This research aims to analyze the influence of organization commitment, human resources competence, utilization of information technology, and the effectiveness of internal control to quality of government financial statement at Talaud Island Regency Government. The sample in this research were the Head and Accounting Staff at Talaud Island Regency Government as 64 respondents. This research is quantitative using multiple regression analysis. To test the data quality by validity and reliability. Beside that testing by the classical assumption of normality, multicollinearity and heteroscedasticity. This research result indicates that organization commitment, utilization of information technology, and the effectiveness of internal control has effect significantly to the quality of government financial statements at Talaud island Regency Government and the human resource competence has effect but not significantly to quality of government financial statement at Talaud Island Regency Government. Suggestions to Talaud Island Regency Government is expected to improve qualifications in the field of education, namely the employees who receive educational background in accounting, as seen from the respondent data, proving that there are many officers who worked in the accounting who have educational non accounting.

Keywords: Quality of Local Government Financial Statements, Organization Commitment, Human Resources Competence, Utilization of Information Technology, and the Effectiveness of Internal Control
\end{abstract}

\section{PENDAHULUAN}

Tuntutan terhadap sektor publik, mewajibkan lembaga-lembaga publik khususnya pemerintah daerah untuk menghasilkan laporan keuangan yang berkualitas. Transparansi dan akuntabilitas dapat terwujud apabila LKPD telah memenuhi beberapa karakteristik kualitatif yang sebagaimana disyaratkan dalam Peraturan Pemerintah No. 71 Tahun 2010 tentang Standar Akuntansi Pemerintahan, yakni relevan, andal, dapat dibandingkan, dan dapat dipahami.

Opini BPK atas LKPD Pemerintah Daerah Kabupaten Kepulauan Talaud pada Tahun 2011 mendapat opini tidak memberikan pendapat (TMP), Tahun 2012 dan 2013 tidak wajar (TW), Tahun 2014 dan 2015 wajar dengan pengecualian (WDP). Meskipun dalam 2 (dua) tahun terakhir Pemerintah Kabupaten Kepulauan Talaud telah mendapat predikat WDP oleh BPK, namun masih terdapat banyak kekurangan dan kendala yang dihadapi dalam penyusunan laporan keuangan terutama pada tingkat SKPD. Menurut pengamatan Bidang Akuntansi DPPKAD Kabupaten Kepulauan Talaud selaku konsolidan dan pengguna laporan keuangan SKPD, masih dijumpai hal-hal sebagai berikut : data yang disajikan tidak akurat, ketidakmampuan SKPD dalam menyajikan pos-pos laporan keuangan dengan tepat, dan Catatan atas Laporan Keuangan (CaLK) yang kurang lengkap dan informatif.

Berdasarkan latar belakang permasalahan, maka dirumuskan permasalahan penelitian ini adalah:

1. Apakah Komitmen Organisasi berpengaruh terhadap Kualitas Laporan Keuangan Pemerintah Daerah di Kabupaten Kepulauan Talaud?

2. Apakah Kompetensi Sumber Daya Manusiaberpengaruh terhadap Kualitas Laporan Keuangan Pemerintah Daerah di Kabupaten Kepulauan Talaud?

3. Apakah Pemanfaatan Teknologi Informasiberpengaruh terhadap Kualitas Laporan 
Keuangan Pemerintah Daerah di Kabupaten Kepulauan Talaud?

4. Apakah Efektivitas Pengendalian Internal berpengaruh terhadap Kualitas Laporan Keuangan Pemerintah Daerah di Kabupaten Kepulauan Talaud?

\section{TINJAUAN PUSTAKA}

\section{Teori Keagenan (Agency Theory)}

Pada teori agensi (agency theory), akuntabilitas publik dapat dimaknai dengan adanya kewajiban pihak pemegang amanah (agent) untuk memberikan pertanggungjawaban, menyajikan, melaporkan, dan mengungkapkan segala aktivitas dan kegiatan yang menjadi tanggungjawabnya kepada pihak pemberi amanah (principal) yang memiliki hak dan kewenangan untuk meminta pertanggungjawaban tersebut (Haryanto et al, 2007 dalam Rosalin, 2011).

\section{Teori Kepatuhan}

Menurut Tyler dalam Septiani (2005) terdapat dua perspektif dasar dalam literatur sosiologi mengenai kepatuhan pada hukum, yang disebut instrumental dan normatif. Perspektif instrumental mengasumsikan individu secara utuh didorong oleh kepentingan pribadi dan tanggapan terhadap perubahan-perubahan dalam tangible, insentif, dan penalti yang berhubungan dengan perilaku. Perspektif normatif berhubungan dengan apa yang orang anggap sebagai moral dan berlawanan dengan kepentingan pribadi mereka.

\section{Laporan Keuangan}

Ikatan Akuntan Indonesia (2012) dalam Standar Akuntansi Keuangan, menyatakan bahwa laporan keuangan merupakan bagian dari proses pelaporan keuangan yang lengkap, biasanya meliputi neraca, laporan laba rugi, laporan posisi keuangan, dan catatan laporan lain serta materi penjelasan yang merupakan bagian integral dari laporan keuangan. Berdasarkan Peraturan Pemerintah Nomor 71 tentang Standar Akuntansi Pemerintahan (SAP), UndangUndang Nomor 17 Tahun 2003 tentang Keuangan Negara dan Undang-Undang Nomor 1 Tahun 2004 tentang Perbendaharaan Negara, bahwa laporan keuangan pemerintah disajikan berdasarkan basis akrual, maka dalam Peraturan Pemerintah Nomor 71 Tahun 2010 tentang Standar Akuntansi Pemerintahan diatur mengenai unsur laporan keuangan pemerintah berbasis akrual, yang terdiri atas Laporan Pelaksanaan Anggaran (terdiri dari Laporan Realisasi Anggaran dan Laporan Perubahan Saldo Anggaran Lebih), Laporan Finansial (terdiri dari Neraca, Laporan Operasional, Laporan Perubahan Ekuitas, dan Laporan Arus Kas), serta Catatan atas Laporan Keuangan.

\section{Kualitas Laporan Keuangan Pemerintah Daerah}

McDaniel et., al (2002), menyatakan untuk menilai kualitas laporan keuangan menggunakan tiga karakteristik yaitu relevance, reliability dan comparibility. Ferdy van Beest, et. al (2009) menulis artikel dengan judul Quality of Financial Reporting: measuring qualitative characteristics. Dalam artikel dinyatakan mereka membangun sebuah alat ukur komprehensif untuk menilai kualitas pelaporan keuangan dalam hal karakteristik kualitatif yang mendasar (misalnya relevan) dan meningkatkan karakteristik kualitatif (understandability, comparability, dan verifiability) seperti yang didefinisikan dalam Kerangka Konseptual untuk Pelaporan Keuangan dari FASB (2008).

Faktor-faktor yang Mempengaruhi Kualitas Laporan Keuangan Pemerintah Daerah Komitmen Organisasi; Robbins dan Judge (2008) mendefinisikan komitmen sebagai suatu keadaan dimana seorang individu memihak organisasi serta tujuan-tujuan dan keinginannya untuk mempertahankan keanggotaannya dalam organisasi.

Kompetensi Sumber daya manusia; Menurut Bastian (2006) bahwa penyiapan dan penyusunan laporan keuangan yang berkualitas memerlukan SDM yang menguasai akuntansi pemerintahan. SDM menjadi faktor kunci dalam menciptakan laporan keuangan yang berkualitas karena yang menyusun laporan keuangan adalah mereka yang menguasai SAP. 
Betapapun bagusnya SAP, tanpa didukung SDM yang handal, maka laporan keuangan yang berkualitas sulit dicapai.

Pemanfaatan Teknologi Informasi; Menurut Junali dan Supomo (2002) pemanfaatan teknologi informasi adalah pemrosesan, pengolahan dan penyebaran data yang didapat dari mengkombinasikan alat perangkat komputer dengan telekomunikasi.

Efektivitas Pengendalian Internal; Dalam Peraturan Pemerintah No. 60 Tahun 2008 ini SPIP didefinisikan sebagai proses yang integral pada tindakan dan kegiatan yang dilakukan secara terus menerus oleh pimpinan dan seluruh pegawai untuk memberikan keyakinan memadai atas tercapainya tujuan organisasi melalui kegiatanyang efektif dan efisien, keandalan pelaporan keuangan, pengamanan aset negara, dan ketaatan terhadap peraturan perundang-undangan.

\section{Gambar 3.1 Kerangka Konseptual}

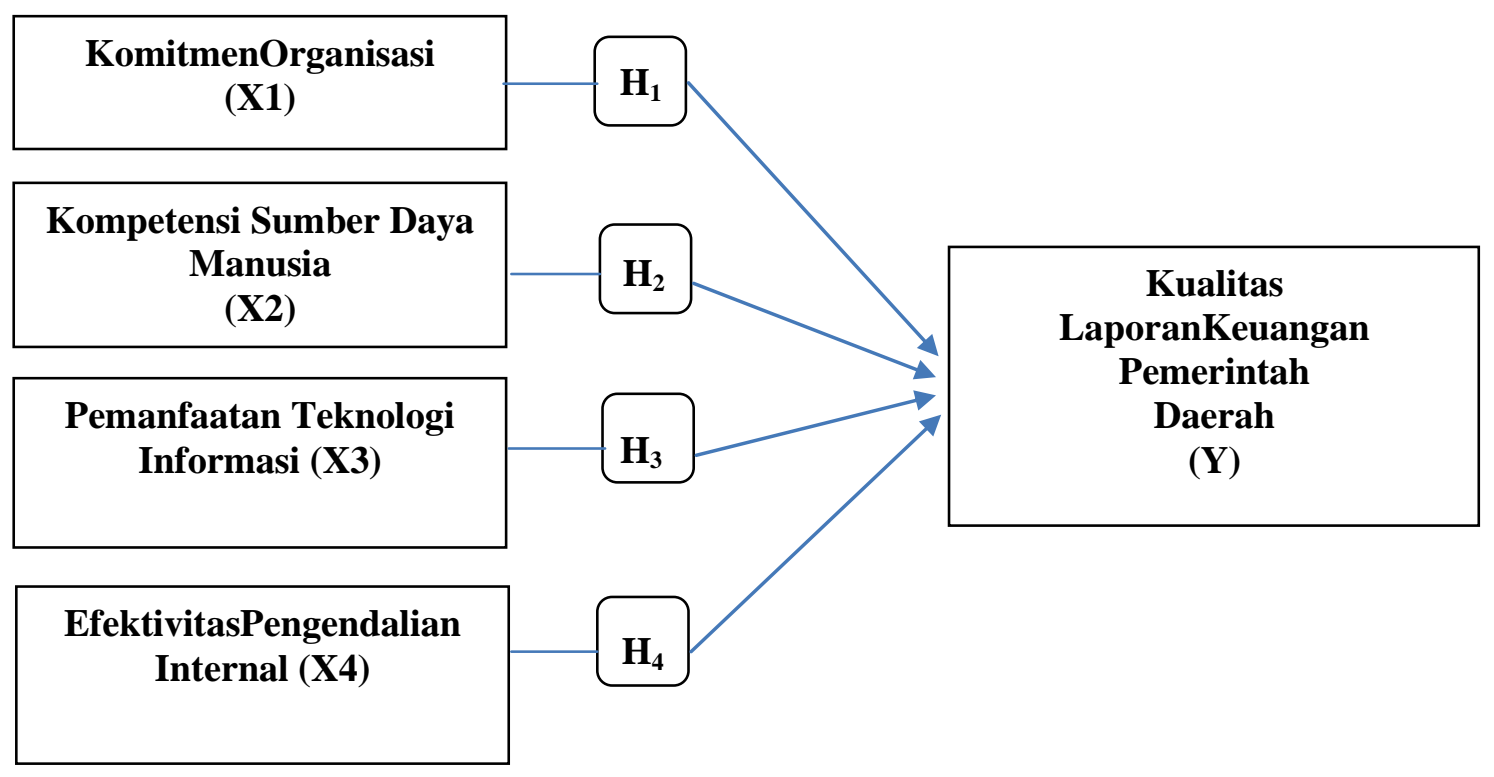

Berdasarkan permasalahan yang telah dikemukakan sebelumnya dan kerangka konseptual tersebut diatas, maka dapat dirumuskan hipotesis sebagai berikut:

1. PengaruhKomitmenOrganisasi terhadap Kualitas Laporan Keuangan Pemerintah Daerah

Setiap pejabat pengelola keuangan daerah harus mengetahui secara utuh apa yang menjadi tugas, wewenang dan tanggung jawabnya sehingga setiap ada perubahan peraturan perundang-undangan siap untuk melaksanakan perubahan tersebut. Secara substansi, istilah komitmen sarat dengan nilai dan sasaran. Istilah tersebut mengandung makna sebuah proses bagaimana nilai dan sasaran tersebut tercapai atau dengan kata lain komitmen merupakan syarat sebuah keberhasilan.

Ha1 : Komitmen Organisasi berpengaruh positif terhadap Kualitas Laporan Keuangan Pemerintah Daerah.

2. PengaruhKompetensiSumber Daya Manusia terhadap Kualitas Laporan Keuangan Pemerintah Daerah

Kaitannya dengan kualitas sumber daya manusia di pemerintah daerah saat ini, menunjukkan bahwa aparat yang memperoleh kuasa dalam mengelola keuangan daerah belum dapat menyusun laporan secara komprehensif (berupa neraca, laporan arus kas, dan laporan realisasi anggaran) disebabkan karena baru memahami sebagian materi atau konsep akuntansi dan manajemen keuangan (Halim, et. al, 2010). 
Ha 2 : Kompetensi Sumber Daya Manusia berpengaruh positif terhadap Kualitas Laporan Keuangan Pemerintah Daerah.

3. PengaruhPemanfaatanTeknologiInformasi terhadap Kualitas Laporan Keuangan Pemerintah Daerah

Pemanfaatan teknologi informasi dipandang sangat membantu dalam menghasilkan laporan keuangan yang berkualitas. Pemerintah daerah dengan bantuan alat untuk mendukung terlaksananya kegiatanatau pekerjaan seperti adanya perangkat keras komputer dan perangkat lunaksehingga dalam pelaksanaan pekerjaan lebih efisien dan lebih tepat waktu dalam penyajian laporan keuangan pemerintah daerah.

$\mathrm{Ha}_{3}$ : Pemanfaatan Teknologi Informasi berpengaruh positif terhadap Kualitas Laporan Keuangan Pemerintah Daerah.

4. PengaruhEfektivitasPengendalian Internal terhadap Kualitas Laporan Keuangan Pemerintah Daerah

Efektivitas pengendalian internal dipandang sangat penting dalam meningkatkan kualitas laporan keuangan.

Ha4: Efektivitas Pengendalian Internal berpengaruh positif terhadap Kualitas Laporan Keuangan Pemerintah Daerah.

\section{Model Analisis}

Penelitian ini akan dilakukan pengujian dengan model analisis regresi linier berganda. Menurut Sugiyono (2015), analisis regresi linier berganda digunakan oleh peneliti bila peneliti bermaksud meramalkan bagaimana keadaan (naik turunnya) variabel dependen bila dua atau lebih variabel independen sebagai faktor prediktor dimanipulasi (dinaik turunkan nilainya) dengan menggunakan formula sebagai berikut :

$\mathbf{Y}=\boldsymbol{\alpha}+\boldsymbol{\beta}_{1} \mathbf{X}_{1}+\boldsymbol{\beta}_{2} \mathbf{X}_{2}+\boldsymbol{\beta}_{3} \mathbf{X}_{3}+\boldsymbol{\beta}_{4} \mathbf{X}_{4}+\varepsilon$

Dimana :

$\mathrm{Y} \quad=\quad$ Kualitas Laporan Keuangan Pemerintah Daerah

$\alpha \quad=$ Konstanta

$\beta_{1,} \beta_{2,} \beta_{3}, \beta_{4}, \quad=\quad$ Koefisien Regresi

$\mathrm{X}_{1} \quad=$ KomitmenOrganisasi

$\mathrm{X}_{2} \quad=$ KompetensiSumber Daya Manusia

$\mathrm{X}_{3} \quad=$ PemanfaatanTeknologiInformasi

$\mathrm{X}_{4} \quad=$ EfektivitasPengendalian Internal

$\varepsilon \quad=$ Error

\section{METODE PENELITIAN}

Jenis Penelitian

Metode yang digunakan dalam penelitian ini adalah metode kuantitatif. Metode kuantitatif dapat diartikan sebagai metode penelitian yang berlandaskan filsafah positivisme, digunakan untuk meneliti pada populasi atau sampel tertentu, teknik pengambilan sampel pada umumnya dilakukan secara purposive, pengumpulan data menggunakan instrument penelitian, analisis data bersifat kuantitatif/statistik dengan tujuan untuk menguji hipotesis yang telah ditetapkan.

\section{Jenis dan Sumber Data}

Penelitian ini menggunakan data kuantitatif yang berbentuk asosiatif yaitu data primer.

1. Data primer dalam penelitian ini akan diperoleh dari responden, melalui kuesioner yang disebarkan.

2. Data sekunder yaitu berupa literatur-literatur kepustakaan yang digunakan sebagai dasar teori yang relevan dengan masalah yang diteliti dan penelitian-penelitian sebelumnya. 


\section{Populasi dan Sampel}

Tabel 4.1Daftar SKPD dan Jumlah Kuesioner yang Dibagikan

\begin{tabular}{|l|l|c|}
\hline No. & \multicolumn{1}{|c|}{ SKPD } & Kuesioner \\
\hline 1 & Sekretariat Daerah & 3 \\
\hline 2 & Sekretariat DPRD & 3 \\
\hline 3 & Inspektorat Kab. Kepl. Talaud & 3 \\
\hline 4 & Badan Kesbang Politik dan Linmas & 3 \\
\hline 5 & Badan Koordinasi Penanaman Modal Daerah & 3 \\
\hline 6 & Badan Pelaksana Penyuluh Pertanian Perikanan dan Kehutanan & 3 \\
\hline 7 & Badan Pemberdayaan Masyarakat dan Pemerintahan Desa & 3 \\
\hline 8 & Badan Penanggulangan Bencana Daerah & 3 \\
\hline 9 & Badan Pengelolaan Kawasan Perbatasan & 3 \\
\hline 10 & Badan Pengelolaan Lingkungan Hidup & 3 \\
\hline 11 & Badan Perencanaan Pembangunan Daerah & 3 \\
\hline 12 & Dinas Kehutanan Pertambangan Dan Energi & 3 \\
\hline 13 & Dinas Kelautan dan Perikanan & 3 \\
\hline 14 & Dinas Kependudukan Dan Catatan Sipil & 3 \\
\hline 15 & Dinas Kesehatan & 3 \\
\hline 16 & Dinas Pariwisata dan Ekonomi Kreatif & 3 \\
\hline 17 & Dinas Pekerjaan Umum & 3 \\
\hline 18 & Dinas Pendapatan Pengelolaan Keuangan dan Aset Daerah & 3 \\
\hline 19 & Dinas Pendidikan dan Kebudayaan & 3 \\
\hline 20 & Dinas Pengelola Pasar Kebersihan dan Pertamanan & 3 \\
\hline 21 & Dinas Perhubungan Komunikasi dan Informatika & 3 \\
\hline 22 & Dinas Perindustrian Perdagangan Koperasi dan UKM & 3 \\
\hline 23 & Dinas Pertanian Perkebunan Dan Peternakan & $\mathbf{7 5}$ \\
\hline 24 & Dinas Sosial Tenaga Kerja Dan Trasmigrasi & \\
\hline 25 & Kantor Satuan Polisi Pamong Praja & JUMLAH \\
\hline & $\quad$ & 3 \\
\hline
\end{tabular}

Sumber: Data Hasil Olahan (2016)

\section{Lokasi dan Waktu Penelitian}

Objek dalam penelitian ini mengambil lokasi di Satuan Kerja Perangkat Daerah di lingkungan Pemerintah Daerah Kabpaten Kepulauan Talaud dengan waktu penelitian selama 3 (tiga) bulan yaitu mulai bulan Juni sampai dengan bulan Agustus 2016.

\section{Cara Pengolahan dan Analisis Data}

\section{Uji Asumsi Klasik}

Uji Normalitas; Menurut Ghozali (2006:147) uji normalitas bertujuan untuk menguji apakah dalam model regresi, variabel dependen dan independen keduanya mempunyai distribusi normal atau tidak.

Uji Multikolinieritas; dimaksudkan untuk mendeteksi gejala korelasi antara variabelindependen yang satu dengan variabel independen yang lain. Pada model regresiyang baik seharusnya tidak terdapat korelasi di antara variabel independen.

Uji Heteroskedastisitas; bertujuan untuk menguji apakah dalam model regresiterjadi ketidaksamaan variance dari residual satu pengamataan ke pengamatanyang lain tetap, atau disebut homoskedastisitas. Model regresi yang baik adalah yang homoskedastisitas, tidak heteroskedastisitas. 


\section{Pengujian Hipotesis}

Untuk membuktikan kebenaran uji hipotesis, digunakan uji statistik terhadap output yang dihasilkan oleh model Regresi Berganda. Uji statistik meliputi:

\section{a. Uji Regresi Secara Simultan (Uji F)}

Uji F dilakukan untuk mengetahui pengaruh variabel-variabel independen secara simultan (bersama-sama) terhadap variabel dependen.

b. Uji Regresi Secara Parsial (Uji t)

Uji t dilakukan untuk mengetahui besarnya pengaruh masing-masing variabel independen secara individual terhadap variabel dependen.

c. Uji Koefisien Korelasi dan Koefisien Determinasi

Uji koefisien korelasi digunakan untuk mengetahui hubungan antara dua atau lebih variabel independen (X1, X2, X3, danX4) terhadap variabel dependen (Y) secara serentak, sedangkan uji koefisien determinasi dalam regresi linear berganda digunakan untuk mengetahui prosentase sumbangan pengaruh variabel independen $(\mathrm{X} 1, \mathrm{X} 2, \mathrm{X} 3$, danX4) secara serentak terhadap variabel dependen (Y).

\section{HASIL ANALISIS DAN PEMBAHASAN}

Gambaran Umum Responden

Tabel 5.1

Pengumpulan Data Penelitian

\begin{tabular}{|c|l|c|c|}
\hline No. & \multicolumn{1}{|c|}{ Keterangan } & Jumlah & Persentase (\%) \\
\hline 1. & Kuesioner yang disebar & 75 & 100 \\
\hline 2. & Kuesioner yang kembali & 65 & 86,7 \\
\hline 3. & Kuesioner yang tidak kembali & 10 & 13,3 \\
\hline 4. & Kuesioner yang dapat diolah & 64 & 85,3 \\
\hline
\end{tabular}

Sumber: Data Olahan (2016)

Tabel 5.2

Komposisi Responden Berdasarkan Jenis Kelamin

\begin{tabular}{|c|c|c|}
\hline Jenis Kelamin & Frekuensi & Persentase (\%) \\
\hline Laki-laki & 37 & 57,8 \\
\hline Perempuan & 27 & 42,2 \\
\hline Jumlah & 64 & 100 \\
\hline
\end{tabular}

Sumber: Data Olahan (2016)

Tabel 5.3

Komposisi Responden Berdasarkan Usia

\begin{tabular}{|c|c|c|}
\hline Usia (Tahun) & Frekuensi & Persentase (\%) \\
\hline $20-30$ & 8 & 12,5 \\
\hline $31-40$ & 26 & 40.6 \\
\hline $41-50$ & 18 & 28,1 \\
\hline$>50$ & 12 & 18,8 \\
\hline Jumlah & 64 & 100 \\
\hline
\end{tabular}

Sumber: Data Olahan (2016)

Tabel 5.4

Komposisi Responden Berdasarkan Pendidikan Terakhir

\begin{tabular}{|c|c|c|}
\hline Pendidikan & Frekuensi & Persentase (\%) \\
\hline SMA & 5 & 7,8 \\
\hline Diploma & 3 & 4,7 \\
\hline S1 & 40 & 62,5 \\
\hline S2 & 16 & 25 \\
\hline Jumlah & 64 & 100 \\
\hline
\end{tabular}

Sumber: Data Olahan (2016) 
Tabel 5.5

Komposisi Responden Berdasarkan Latar Belakang Pendidikan

\begin{tabular}{|c|c|c|}
\hline Latar Belakang Pendidikan & Frekuensi & Persentase (\%) \\
\hline Akuntansi & 9 & 14,1 \\
\hline Ekonomi & 21 & 32,8 \\
\hline Sospol & 3 & 4,7 \\
\hline Hukum & 7 & 10,9 \\
\hline Lainnya & 24 & 37,5 \\
\hline Total & 64 & 100 \\
\hline
\end{tabular}

Sumber: Data Olahan (2016)

Tabel 5.6

Komposisi Responden Berdasarkan Lama Waktu Bekerja

\begin{tabular}{|l|c|c|}
\hline \multicolumn{1}{|c|}{ Pengalaman Kerja } & Frekuensi & Persentase (\%) \\
\hline$<1$ tahun & 6 & 9,4 \\
\hline $1-5$ tahun & 17 & 26,5 \\
\hline$>5$ tahun & 41 & 64,1 \\
\hline Total & 64 & 100 \\
\hline
\end{tabular}

\section{Pembahasan}

Penelitian ini untuk menguji pengaruh komitmen organisasi, kompetensi SDM, pemanfaatan teknologi informasi, dan efektivitas pengendalian internal terhadap kualitas laporan keuangan. Berdasarkan pengujian hipotesis dengan menggunakan analisis regresi berganda didapatkan hasil sebagaimana ditampilkan pada tabel 5.20.

Tabel 5.20

Hasil Uji Hipotesis

\begin{tabular}{|l|c|}
\hline \multicolumn{1}{|c|}{ Hipotesis } & $\begin{array}{c}\text { Hasil } \\
\text { Pengujian }\end{array}$ \\
\hline $\begin{array}{l}\text { Komitmen organisasi berpengaruh positif terhadap kualitas laporan } \\
\text { keuangan pemerintah daerah }\left(\mathrm{H}_{\mathrm{a} 1}\right)\end{array}$ & Diterima \\
\hline $\begin{array}{l}\text { Kompetensi SDM berpengaruh positif terhadap kualitas laporan keuangan } \\
\text { pemerintah daerah }\left(\mathrm{H}_{\mathrm{a} 2}\right)\end{array}$ & Ditolak \\
\hline $\begin{array}{l}\text { Pemanfaatan teknologi informasi berpengaruh positif terhadap kualitas } \\
\text { laporan keuangan pemerintah daerah }\left(\mathrm{H}_{\mathrm{a} 3}\right)\end{array}$ & Diterima \\
\hline $\begin{array}{l}\text { Efektivitas pengendalian internal berpengaruh positif terhadap kualitas } \\
\text { laporan keuangan pemerintah daerah }\left(\mathrm{H}_{\mathrm{a} 4}\right)\end{array}$ & Diterima \\
\hline
\end{tabular}

Sumber:Hasil Olah Data SPSS (2016)

\section{Pengaruh komitmen organisasi terhadap kualitas laporan keuangan}

Hasil pengujian hipotesis pertama menunjukkan bahwa pada komitmen organisasi, $\mathrm{t}_{\text {hitung }}=$ $4,910>\mathrm{t}_{\text {tabel }}=2,00100$ sehingga komitmen organisasi berpengaruh secara signifikan terhadap kualitas laporan keuangan. Nilai koefisien regresi komitmen organisasi sebesar 0,370 menunjukkan bahwa penambahan satu satuan komitmen organisasi akan menambah kualitas laporan keuangan sebesar 0,370 satuan.

\section{Pengaruh kompetensi SDM terhadap kualitas laporan keuangan}

Hasil pengujian hipotesis kedua menunjukkan bahwa pada kompetensi SDM $t_{\text {hitung }}=1,482$ $<\mathrm{t}_{\text {tabel }}=2,00100$ sehingga kompetensi SDM tidak berpengaruh secara signifikan terhadap kualitas laporan keuangan. Nilai koefisien regresi kompetensi SDM sebesar 0,165 menunjukkan bahwa penambahan satu satuan kompetensi SDM hanya akan menambah kualitas laporan keuangan sebesar 0,165 satuan. 


\section{Pengaruh pemanfaatan teknologi informasi terhadap kualitas laporan keuangan}

Hasil pengujian hipotesis ketiga menunjukkan bahwa pada teknologi informasi $t_{\text {hitung }}=$ $3,201>\mathrm{t}_{\text {tabel }}=2,00100$ sehingga pemanfaatan teknologi informasi berpengaruh secara signifikan terhadap kualitas laporan keuangan. Nilai koefisien regresi pemanfaatan teknologi informasi sebesar 0,396 menunjukkan bahwa penambahan satu satuan teknologi informasi akan menambah kualitas laporan keuangan sebesar 0,396 satuan.

\section{Pengaruh efektivitas pengendalian internal terhadap kualitas laporan keuangan}

Hasil pengujian hipotesis keempat menunjukkan bahwa pada efektivitas pengendalian internal, thitung $=2,605>$ ttabel $=2,00100$ sehingga efektivitas pengendalian internal berpengaruh secara signifikan terhadap kualitas laporan keuangan. Nilai koefisien regresi efektivitas pengendalian internal sebesar 0,284 menunjukkan bahwa penambahan satu satuan efektivitas pengendalian internal akan menambah kualitas laporan keuangan sebesar 0,284 satuan.

\section{KESIMPULAN DAN SARAN \\ Kesimpulan}

Dari hasil penelitian disimpulkan bahwa :

a.Dari hasil uji t atau secara parsial, dapat disimpulkan bahwa variabel komitmen organisasi (X1) berpengaruh secara signifikan terhadapkualitas LKPD (Y) pada Pemerintah Daerah Kabupaten Kepulauan Talaud, karena penambahan satu satuan komitmen organisasi akan menambah kualitas laporan keuangan sebesar 0,370 satuan;

b.Variabel kompetensi SDM (X2) tidak berpengaruh secara signifikan terhadap kualitas LKPD (Y) pada Pemerintah Daerah Kabupaten Kepulauan Talaud, karena penambahan satu satuan kompetensi SDM hanya akan menambah kualitas laporan keuangan pemerintah daerah sebesar 0,165 satuan;

c.Variabel pemanfaatan teknologi informasi (X3) berpengaruh secara signifikan terhadapkualitas LKPD (Y) pada Pemerintah Daerah Kabupaten Kepulauan Talaud, karena penambahan satu satuan pemanfaatan teknologi informasi akan menambah kualitas laporan keuangan sebesar 0,396 satuan;

d.Variabel efektivitas pengendalian internal (X4) berpengaruhsecara signifikan terhadapkualitaslaporan keuangan (Y) pada Pemerintah Daerah Kabupaten Kepulauan Talaud, karena penambahan satu satuan efektivitas pengendalian internal akan menambah kualitas laporan keuangan sebesar 0,284 satuan;

e.Dari hasil uji f atau secara simultan, dapat disimpulkan bahwa variabel komitmen organisasi (X1), Kompetensi SDM (X2), pemanfaatan teknologi informasi (X3) dan efektivitas pengendalian internal (X4)secara bersama-sama berpengaruh secara signifikan terhadap kualitas laporan keuangan (Y) pada Pemerintah Daerah Kabupaten Kepulauan Talaud;

\section{Saran}

Berdasarkan kesimpulan di atas, adapun beberapa saran dapat disajikan sebagai berikut :

1.Saran bagi Pemerintah Daerah Kabupaten Kepulauan Talaud, agar dapat :

2.Meningkatkan komitmen organisasi pimpinan instansi dan pegawai pengelola keuangan. Pertama pimpinan instansi sebagai pelaksana pengendalian internal harus memiliki komitmen organisasi yang kuat dalam melaksanakan sistem pengendalian internal dengan merumuskan dan menerapkan standar pengendalian internal. Kedua bagi pegawai pengelola keuangan untuk terus meningkatkan komitmen organisasi dalam mendukung pelaksanaan tugas pengelolaan keuangan untuk menghasilkan laporan keuangan yang berkualitas.

3.Meningkatkan kompetensi sumber daya manusia pegawai pengelola keuangan. Pertama pimpinan pemda mendorong dan memberikan fasilitas tugas belajar kepada pegawai pengelola keuangan untuk melanjutkan studi dalam bidang akuntansi. Kedua meningkatkan 
keterlibatan pegawai pengelola keuangan dalam pelatihan atau kursus tentang pengelolaan keuangan daerah. Ketiga penempatan pegawai pengelola keuangan di SKPD harus sesuai dengan kompetensi sumber daya manusia yang dimiliki.

4.Saran untuk penelitian berikutnya:

5.Peneliti selanjutnya diharapkan dapat menambah variabel independen lain yang belum diteliti pada penelitian ini agar dapat mengetahui faktor-faktor lain yang mungkin mempengaruhi kualitas laporan keuangan pemerintah daerah.

6.Peneliti selanjutnya dapat mempertimbangkan menggunakan metode metode campuran kuantitatif dan kualitatif dalam penelitian, dimana metode kualitatif digunakan untuk menjelaskan hasil yang diperoleh dari metode kuantitatif sehingga dapat memperoleh kesimpulan yang sesuai dengan kondisi sebenarnya.

\section{DAFTAR PUSTAKA}

Aidil, 2010, Faktor-faktor yang Mempengaruhi Kemampuan Penyusunan Laporan Keuangan Pemerintah Daerah (Studi Empiris pada Pemerintah Kota Tebing Tinggi), USU, Medan.

Aranya, N., and K.R Ferris (1984). "A Reexamination of Accountant OrganizationalProfessional Conflict". The Accounting Review. 59.pp 1-15.

Azhar.2007. Faktor-Faktor yang Mempengaruhi Keberhasilan Penerapan Permendagri Nomor 13 pada Pemerintah Kota Banda Aceh. Tesis. Program Pascasarjana USU. Medan.

Bastian, I. 2006. Akuntansi Sektor Publik: Suatu Pengantar. Jakarta: Erlangga.

BPK RI, 2014, Ikhtisar Hasil Pemeriksaan Semester I Tahun 2014, Jakarta , 2015, Ikhtisar Hasil Pemeriksaan Semester I Tahun 2015, Jakarta.

Committe of Sponsoring Organizations of the Treadway Commision (COSO), 1994. Internal Control-Integrated Framework. AICPA Publication.

Darlis,Edfan.2002.AnalisisPengaruh Komitmen Organisasional danKetidakpastian LingkunganterhadapHubungan antara PartisipasiAnggaran denganSenjangan Anggaran.Jurnal RisetAkuntansi Indonesia. UniversitasRiau. (Vol.5).Januari.HIm.85 100.

Desi dan Ertambang, 2008,Pengaruh Kapasitas Sumber Daya Manusia, Pemanfaatan Teknologi Informasi dan Pengendalian Intern Akuntansi Terhadap Nilai Informasi Pelaporan Keuangan Pemerintah Daerah.

Ecivahyani, Sagung Inten. 2015. Analisis Faktor-faktor yang Mempengaruhi Kualitas Laporan Keuangan Pemerintah Daerah Kabupaten Tabanan. Tesis. Program Pascasarjana Universitas Udayana Denpasar.

Ferdy Van Beest, Geert Braam, and Suzanne Boelens. 2009. Quality of Financial Reporting: Measuring Qualitative Characteristics. Nijmegen Center for Economics (NiCE). Working Paper 09-108 April.

Gaa and Thore, 2004, Basic Accounting Education in Asia, Education of Journal, Elsevier, London.

Gafarov, T. 2009. Financial Reporting Quality Control for Internal Control Implementation. A. Disertasi For the award of Doctor of Philosophy, Business and Management Faculty Institude of Finances, Brno University of Technology.

Ghozali, I. 2006. Aplikasi Analisis Multivariate Dengan Program SPSS. Cetakan Keempat. Semarang: Badan Penerbit Universitas Diponegoro.

Guy, Dan M., Alderman, C. Wayne dan Winters, Alan J. 2002.Auditing:Jilid 1. Jakarta:Erlangga.

Halim, Abdul, 2007, Akuntansi dan Pengendalian Pengelolaan Keuangan Daerah, Edisi Revisi, UPP STIM YKPN, Yogyakarta. 2007, Pengelolaan Keuangan Daerah, Edisi Kedua, UPP STIM YKPN, Yogyakarta. 
2010, Sistem Akuntansi Sektor Publik, Edisi Pertama, UPP STIM YKPN, Yogyakarta.

Hilton, R. W., Michael, W. M. And Frank, H. S. 2000. Cost Management, Strategies for Business Decision. International Edition. McGraw-Hill Companies, Inc.

Horngren, C. T., G.Foster, and S. M. Datar. 2003. Cost Accounting: AManagerial Emphasis. $11^{\text {th }}$ Edition. Pretice-Hall International. Inc.

Indriasari dan Nahartyo, 2008,Pengaruh Kapasitas Sumber Daya Manusia, Pemanfaatan Teknologi Informasi, Dan Pengendalian Intern Akuntansi Terhadap Nilai Informasi Pelaporan Keuangan Pemerintah Daerah.

Ikatan Akuntan Indonesia. 2012.Standar Akuntansi Keuangan.PSAK. Cetakan Keempat. Buku Satu. Jakarta : Penerbit Salemba Empat

Jensen, M, and W. Theory, Meckling, Of The Firm: Managerial (1976), Behavior,Agency "Cost and Ownership Strukture”. Journal Of Financial Economics, (3): 305-360.

Junali, Teddy dan Bambang Supomo. 2002. Pengaruh Faktor-faktor Kesesuaian Tugas Teknologi dan Pemanfaatan Teknologi Informasi terhadap Kinerja Akuntan Publik. Jurnal Riset Akuntansi Indonesia Vol.5 No.2, Hal.214-228.

Laudon, K. C., Jane P. Laudon. 2006. Management Information System. 9th edition. New Jersey : Prentice-Hall, Inc

Mahaputra dan Wayan, 2014. Analisis Faktor-Faktor yang Mempengaruhi Kualitas Informasi Pelaporan Keuangan Pemerintah Daerah: E-Jurnal Akuntansi Universitas Udayana.

Mardiasmo, 2009, Akuntansi Sektor Publik, Andi, Yogyakarta.

Martin, E. W., C. W. Brown, D. W. DeHayes, J. A. Hofer, dan W. C. Perkins. 2002. Managing Information Technology. New Jersey : Prentice-Hall, Inc.

McDaniel. Linda, Roger D Mrtin and Laureen A. Maines, 2002,Evaluating Financial Reporting Quality. Accounting Review. December 1

Meyer, J. P. and N. J. Allen. 1997. Commitment in the Workplace: Theory, Research and Application. Journal of Vacation Behavior.(Vol. 14): 24-27.

Mowdey, R. T., R. M. Steers, and L. W. Porter. 1979. The Measurement of Organizational Commitment. Journal of Vocational Behaviour. (Vol. 14): 224-247.

Nuryanto M. dan N. N. Afiah. 2013. The Impact of Apparatus Competence, Information Technology Utilization and Internal Control on Financial Statement Quality (Study on Local Government of Jakarta Province - Indonesia). World Review of Business Research. (Vol. 3): No. 4. November 2013 Issue. Pp. $157-17$.

Peraturan Menteri Dalam Negeri Nomor 13 Tahun 2006 tentang Pedoman Pengelolaan Keuangan Daerah.

Peraturan Menteri Dalam Negeri Nomor 59 Tahun 2007 tentang Perubahan Atas Peraturan Menteri Dalam Negeri Nomor 13 Tahun 2006 tentang Pedoman Pengelolaan Keuangan Daerah.

Pangkong, Terry Corie. 2013. Faktor-faktor yang Mempengaruhi Kemampuan Penyusunan Laporan Keuangan Pemerintah Daerah di Kabupaten Biak Numfor. Tesis. Program Magister Akuntansi Universitas Sam Ratulangi Manado.

Ponamon Irene Fransisca. 2014. Pengaruh Pengawasan Internal, Pemahaman Sistem Akuntansi Keuangan, dan Kapasitas Sumber Daya Manusia Terhadap Kualitas Informasi Laporan Keuangan Pemerintah pada SKPD Pemerintah Kota Manado.

Pradono, F. C. dan Basukiato. 2015. Kualitas Laporan Keuangan Pemerintah Daerah: Faktor yang Mempengaruhi dan Implikasi Kebijakan (Studi pada SKPD Pemerintah Jawa Tengah). Jurnal Bisnis dan Ekonomi, Vol.22. No.2 September 2015, Hal.188-200. ISSN 1412-3126. 
Ratifah, Ifa. 2014. Komitmen Organisasi Memoderasi Pengaruh Sistem Akuntansi Keuangan Daerah terhadap Kualitas Laporan Keuangan di Pemerintah Daerah Kabupaten Karawang

Robbins, Stephen P, Judges, Timothy A, 2008, Perilaku Organisasi, Edisi 12, Salemba Empat, Jakarta.

Rosalin, Faristina, 2011,Pengaruh Penggunaan Teknologi Informasi dan Keahlian Pemakai Terhadap Kualitas Informasi Akuntansi Studi pada BLU di Kota Semarang.

Prayitno, Tim Peneliti BKN. 2003.Pedoman Penyusunan Standar Kompetensi Jabatan Pegawai Negeri Sipil. Puslitbang BKN, Jakarta.

Saerang,D. P. E.dan H. R. N. Wokas. 2011. Pengaruh Komitmen, dan Pendidikan Terhadap Kemampuan Penyusunan Laporan Keuangan SKPD Pemerintah Daerah Sulawesi Utara.

Sudiarianti, Ni Made. 2015.Pengaruh Kompetensi Sumber Daya Manusia pada Penerapan Sistem Pengendalian Intern Pemerintah dan Standar Akuntansi Pemerintah serta Implikasinya pada Kualitas Laporan Keuangan Pemerintah. Tesis. Program Pascasarjana Universitas Udayana Denpasar.

Syarifudin, Akhmad. 2014. Pengaruh Kompetensi SDM dan Peran Audit Intern terhadap Kualitas Laporan Keuangan Pemerintah Daerah dengan Variabel Intervening Sistem Pengendalian Internal Pemerintah (studi empiris pada Pemkab Kebumen). Jurnal Fokus Bisnis, Vol.14. No.02 Desember 2014, Hal.26-44.

Sekaran, U, 2006,Metodologi Penelitian untuk Bisnis. Jakarta: Penerbit Salemba Empat.

Septiani, Aditya, 2005,Faktor-Faktor Yang Mempengaruhi Ketepatwaktuan Pelaporan Keuangan Pada Pasar Modal Yang Sedang Berkembang; Perpektif Teori Pengungkapan.

Silviana, 2012,Pengaruh Komitmen Kepala Daerah Terhadap Kualitas Laporan Keuangan Pemerintah Daerah di Provinsi Jawa Barat.

Sopiah, 2008, Perilaku Organisasi, Andi, Yogyakarta

Stephen J. Gauthier, 2007,Interpreting Local Government Financial Statement. Government Finance Review.

Sukmaningrum, Tantriani, 2012,Analisis Faktor-Faktor Yang Mempengaruhi Kualitas Informasi Laporan Keuangan Pemerintah Daerah.

Sugiyono. 2014. Metode Penelitian Kuantitatif, Kualitatif, Dan R\&D. Bandung: Alfabeta.

Sugiyono. 2015.Metode Penelitian Kuantitatif, Kualitatif, dan Kombinasi (Mixed Methods). Bandung : Alfabeta.

Suwanda D. 2015,Factors Affecting Quality of Local Government Financial Statements to Get Unqualified Opinion (WTP) of Audit Board of the Republic of Indonesia $(B P K)$.Research Journal of Finance and Accounting(Paper) ISSN 2222-2847 (Online)(Vol.6): No.4.

Warisno, 2009, Faktor-faktor yang Mempengaruhi Kinerja SKPD di Lingkungan Pemerintah Provinsi Jambi, USU, Medan.

Warongan, J. D. L. 2015.Determinan Efektivitas Pengendalian Internal dan Pengaruhnya terhadap Kualitas Laporan Keuangan Pemerintah Daerah di Sulawesi Utara. Disertasi. Program Doktor Ilmu Ekonomi dan Bisnis Universitas Hasanuddin Makassar.

Wilkinson, J. W., Cerullo, M. J., Raval, V., and Wong-On-Wing, B. 2000. Accounting Information System: Essential Concepts and Applications. New York: John Wiley \& Sons. Inc.

Winidyaningrum, Celviana dan Rachmawati. 2010.Pengaruh Sumber Daya Manusia dan Pemanfaatan Teknologi Informasi terhadap Keterandalan dan Ketepatwaktuan Pelaporan Keuangan Pemerintah Daerah dengan Variabel Intervening Pengendalian 
Intern Akuntansi (Studi Empiris di Pemda Subosukawonosraten). SNA XIII. 13-14 Oktober. Purwokerto.

Zainani, Elva. 2013.Pengaruh Faktor Internal dan Eksternal terhadap Keterandalan dan Ketepatwaktuan Pelaporan Keuangan Pemerintah Daerah (Studi Empiris pada Pemerintah Daerah Kabupaten Pesaweran). Jurnal.

Zuliarti, 2012,Pengaruh Kapasitas Sumber Daya Manusia,Pemanfaatan Teknologi Informasi, dan Pengendalian Intern Akuntansi Terhadap Nilai Informasi Pelaporan Keuangan Pemerintah Daerah : Studi Pada Pemerintah Kabupaten Kudus. 